\title{
Co-resistance to Chromium and Antibiotics in Bacteria Isolated from Tannery Wastes
}

\author{
J alish Mahmud", Miraj Kobad Chowdhury", Abdullah Bashar Sami, \\ Anwarul Azim Akhand and Nazmul Ahsan
}

\author{
Department of Genetic Engineering and Biotechnology, University of Dhaka, Dhaka-1000, Bangladesh
}

Received: November 03, 2015; Accepted: January 21, 2016; Published (web): January 31, 2016

\begin{abstract}
Bacteria isolated from tannery wastes were evaluated for their resistance towards chromium $(\mathrm{Cr})$ as well as antibiotics. Out of the twelve isolates, three bacterial strains showed $\mathrm{Cr}$ resistance even at $10 \mathrm{mg} / \mathrm{ml}$ concentration and were cocci in shape. Antibiogram suggested that these Cr-resistant bacteria were also resistant to multiple antibiotics. This study suggested that exposure to $\mathrm{Cr}$ in the environment can also lead to the development of antibiotic resistant microorganisms. Future research will disclose the mechanism underlying the existence of such dual resistance and also its impact on public health.
\end{abstract}

Key words: Tannery wastes, heavy metal, chromium resistance, antibiotic resistance, public health

\section{INTRODUCTION}

Although heavy metals are essential micronutrients for the growth and enzymatic activities of organisms, these heavy metals are toxic at elevated concentration. ${ }^{1,2}$ Excess heavy metals boost the oxidative stress by increasing the production of reactive oxygen species (ROS) and such ROS may ultimately cause cytotoxic and genotoxic effects. ${ }^{3,4}$ However, microorganisms are known to be capable of adapting rapidly to heavy metal toxicity mostly by gaining mutations, by nonspecific adsorption phenomenon or by the spreading of the resistance transfer factor (Rfactors).$^{5-7}$ Such alterations of their activities usually support the plasticity of microbial community and may ensure the possibility of environmental reclamation. ${ }^{8}$ Recent studies suggested that resistance to heavy metals or regulation of heavy metalresistance pathways may contribute to the development of antibiotic resistant bacterial strains. ${ }^{9}$

Correspondence to: Nazmul Ahsan

Phone: 880-2- 9661920 Ext. 7822; Fax: 880-2-8615583

Email:nahsan@du.ac.bd

${ }^{\pi}$ Equal contribution

Dhaka Univ. J. Pharm. Sci. 14(2): 193-197, 2015 (December)
For example, multidrug resistant E. coli was isolated from the intestine of farm animals receiving zinc as feed supplement. ${ }^{10}$ Some of the heavy metal resistance pathways, like efflux pumps or capsular modifications, have been considered to provide crossresistance to antibiotics in microorganisms. ${ }^{11}$ As $\mathrm{R}$ factor is a plasmid that often contains one or several antibiotic-resistance genes, heavy metal-resistance genes might, therefore, be linked with multi-drug resistance genes in such bacterial plasmids. ${ }^{12,13}$ Thus, individual bacterial strain gains stress resistance to different toxicity. Combined resistance to heavy metal and antibiotic occurs mainly due to selective pressure in presence of heavy metal rather than accidental exposure to antibiotics or heavy metals or both. $^{14}$

Among various heavy metals, chromium $(\mathrm{Cr})$ has widespread industrial uses in leather tanning, wood preservation, electroplating, pigment manufacturing etc. ${ }^{15}$ Inappropriate disposal of residual $\mathrm{Cr}$ and $\mathrm{Cr}$-containing by-products into the environment is causing severe pollution. ${ }^{4}$ While the industrial usage of $\mathrm{Cr}$ compounds are accepted, key 
issues remained whether inappropriate disposal of these compounds are creating a selective pressure on the microbial flora around the dumping sites leading to emergence of Cr-resistant microbes or not. Also, emergence of antibiotic-resistant bacteria has become a critical public health hazard. Widespread overuse, misuse, and abuse of antibiotics in medicine and agriculture are considered as key contributing factors for such emergence. ${ }^{16}$ Since heavy metal resistant bacteria may also exhibit antibiotic resistance, there is a possibility of such exposure to $\mathrm{Cr}$ compounds may also contributing to the development of coresistance to antibiotics. We observed co-resistance to $\mathrm{Cr}$ and antibiotics in microorganisms isolated from tannery wastes. The results of this study revealed that Cr-resistance developed in microorganisms from continuing exposure to $\mathrm{Cr}$ dumped from tannery industries might also contribute to the development of multi-drug resistance in these microorganisms even in the absence of antibiotics themselves.

\section{MATERIALS AND METHODS}

Isolation and characterization of $\mathrm{Cr}$-resistant microorganisms. Wastes from tannery industries at the Hazaribagh area, Dhaka, Bangladesh were collected in sterile $50 \mathrm{ml}$ tubes. Samples were streaked on Luria-Biritani (LB, Scharlau Chemie, Spain) agar plates containing $0.5 \mathrm{mg} / \mathrm{ml}$ filter $(0.22$ $\mu \mathrm{m}$ pore $)$ sterilized chromate $\left(\mathrm{K}_{2} \mathrm{CrO}_{4}\right.$, Scharlau Chemie, Spain) and incubated overnight at $37{ }^{\circ} \mathrm{C}$. Next day, individual bacterial colonies showing $\mathrm{Cr}$ resistance were picked and cultured in LB media containing $0.5 \mathrm{mg} / \mathrm{ml}$ chromate to get pure culture. Pure cultures were preserved for further use. Individual bacterial strains were characterized by visual observation of colony and also by Gram staining and other tests with standard protocols. ${ }^{17}$

Evaluation of $\mathrm{Cr}$-resistance of the isolates. Individual isolates were cultured in LB media containing $0.5 \mathrm{mg} / \mathrm{ml}$ chromate up to $0.5 \mathrm{McFarland}$ standard. Culture $(100 \mu \mathrm{l})$ was then transferred in 5.0 $\mathrm{ml}$ LB media containing different concentrations of chromate ranging from 0 to $10 \mathrm{mg} / \mathrm{ml}$. After overnight incubation at $37{ }^{\circ} \mathrm{C}$, growth was determined by spectrophotometer at $600 \mathrm{~nm}$. A Crsensitive E. coli was used as a control. All these experiments were repeated three times and statistical analysis was done using Microsoft Excel v2010.

Evaluation of antibiotic-resistance of the isolates. Individual isolates were cultured up to 0.5 McFarland standards in LB media containing 0.5 $\mathrm{mg} / \mathrm{ml}$ chromate. Antibiotic resistance were determined by Kirby-Bauer disc diffusion method. ${ }^{18}$ For this, $100 \mu \mathrm{l}$ of the above culture was spread on Muller-Hinton agar (Difco, USA) plate. Antibiotic discs (Oxoid, England) were then placed and incubated overnight at $37^{\circ} \mathrm{C}$. After that, zone of inhibition was measured in millimetres and compared with the standard chart to determine their sensitivity. ${ }^{19}$ Antibiotic discs (Oxoid, England) used for this experiment were gentamicin, ceftriaxone, imipenem, ampicillin, erythromycin, ceftazidime and amoxicillin. All these experiments were repeated three times and statistical analysis was done using Microsoft Excel v2010.

\section{RESULTS AND DISCUSSION}

Isolation of Cr-resistant bacteria from tannery wastes. Microbial flora of tannery area is in regular exposure to $\mathrm{Cr}$ compounds used during leather processing. This can lead to the development of Cr-resistant microorganisms. ${ }^{20}$ Here, we have successfully isolated twelve individual bacterial colonies from the collected tannery waste samples (data not shown). Among them, three isolates were capable to grow in LB media containing $10 \mathrm{mg} / \mathrm{ml}$ Cr. Interestingly, all of them were cocci, but isolates 1 and 2 were Gram positive and the isolate 3 was Gram negative (Table 1). The growth patterns of isolate 1 with chromate $(1 \mathrm{mg} / \mathrm{ml})$ or without chromate were comparable. But, growth was reduced in other isolates at the same concentration (Figure 1). Also, all of the isolates showed reduced growth at 10 $\mathrm{mg} / \mathrm{ml}$ chromate. In comparison, isolate 1 showed the most resistance to $\mathrm{Cr}$ followed by isolate 3 , and the least growth was observed in isolate 2 (Figure 1). The results indicated that these isolates were $\mathrm{Cr}$ resistant. 
Table 1. Morphological characteristics of bacteria isolated from tannery wastes.

\begin{tabular}{lllll}
\hline Characteristics & \multicolumn{3}{c}{ Isolates } & Control \\
\cline { 2 - 5 } & Isolate 1 & Isolate 2 & Isolate 3 & E. coli \\
\hline Colony morphology & Yellow, circular, & White, oval, Rough, & White, irregular, small, & White, shiny, mucoid \\
& smooth, wet & dry & flat & \\
Gram staining & Gram +ve & Gram+ve & Gram-ve & Gram-ve \\
Shape & Cocci & Cocci & Cocci & Rod \\
Motility & Non-motile & Non-motile & Non-motile & Motile \\
Capsule staining & Encapsulated & Encapsulated & Encapsulated & Encapsulated \\
\hline
\end{tabular}

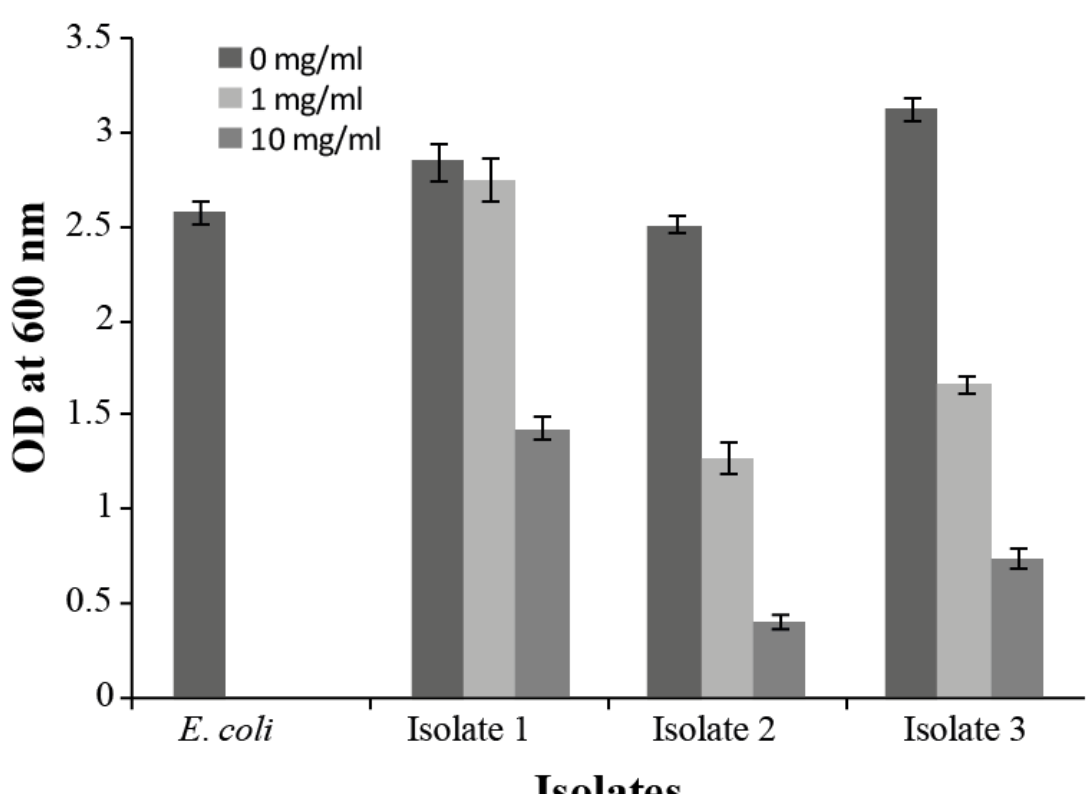

Figure 1. Chromium resistance of bacteria isolated from tannery wastes: The isolates showed significant growth compared to a Cr-sensitive E. coli control. LB media with $10 \mathrm{mg} / \mathrm{ml}$ chromate was used as a blank. The values are the means of at least three independent experiments performed.

Cr-resistant bacteria also showed resistance against multiple antibiotics. Resistance to heavy metal may lead to the development of antibiotic resistance due to co-evolution or sharing of the heavy metal resistance pathways. ${ }^{13}$ These Cr-resistant bacteria were, therefore, evaluated for multi-drug resistance. Table 2 shows the antibiogram of these isolates. The results revealed that the isolates were either sensitive or resistant to various antibiotics used in this study. We observed that the isolates were mainly resistant to the beta-lactam group of antibiotics such as imipenem, ceftazidime and amoxicillin; however, they were sensitive to gentamycin, ceftriaxone and ampicillin. Among the three isolates, isolate 3 showed intermediate resistances to imipenem and ceftazidime. Interestingly, isolate 1 showing the highest growth in presence of higher concentrations of $\mathrm{Cr}$ compared to isolate 2 and 3 also showed resistant to more different types of antibiotics tested (Table 2). This data suggests that $\mathrm{Cr}$ resistance in these isolates could be associated with antibiotic resistance. These $\mathrm{Cr}$ resistant isolates thus possibly have an effective systems or metabolic pathways offering them to show antibiotic resistance concurrently. ${ }^{2,12}$ 
Table 2. Mean diameter of the zones of bacterial inhibition by the antibiotic tested. Diameter of zone of inhibition (DZOI) is given in millimetres \pm standard deviation.

\begin{tabular}{lcccccccc}
\hline \multirow{2}{*}{$\begin{array}{l}\text { Antibiotics } \\
\text { (potency in } \mu \mathrm{g})\end{array}$} & \multicolumn{9}{c}{ Isolates } & \multicolumn{2}{c}{ Isolate 3 } & \multicolumn{2}{c}{ Eontrol } \\
\cline { 2 - 9 } & \multicolumn{2}{c}{ Isolate 1 } & \multicolumn{2}{c}{ Isolate 2} & Doli \\
\cline { 2 - 9 } & DZOI & Comment & DZOI & Comment & DZOI & Comment & DZOI & Comment \\
\hline Gentamicin (10) & $27.6 \pm 0.5$ & Sensitive & $24.6 \pm 0.6$ & Sensitive & $27.3 \pm 0.8$ & Sensitive & $30.0 \pm 0.5$ & Sensitive \\
Ceftriaxone (30) & $26.0 \pm 0.6$ & Sensitive & $28.0 \pm 0.5$ & Sensitive & $28.3 \pm 0.7$ & Sensitive & $29.0 \pm 0.5$ & Sensitive \\
Imipenem (10) & $10.0 \pm 0.5$ & Resistant & $12.6 \pm 0.7$ & Resistant & $14.0 \pm 0.5$ & Intermediate & $16.0 \pm 0.5$ & Sensitive \\
Ampicillin (10) & $22.3 \pm 0.6$ & Sensitive & $26.0 \pm 0.5$ & Sensitive & $29.7 \pm 0.8$ & Sensitive & $8.0 \pm 0.5$ & Resistant \\
Erythromycin (15) & $0.0 \pm 0.0$ & Resistant & $25.0 \pm 0.5$ & Sensitive & $26.0 \pm 0.5$ & Sensitive & $27.0 \pm 0.5$ & Sensitive \\
Ceftazidime (30) & $8.4 \pm 0.6$ & Resistant & $13.3 \pm 0.8$ & Resistant & $17.3 \pm 0.5$ & Intermediate & $22.0 \pm 0.0$ & Sensitive \\
Amoxicillin (25) & $0.0 \pm 0.0$ & Resistant & $0.0 \pm 0.0$ & Resistant & $0.0 \pm 0.0$ & Resistant & $28.0 \pm 0.5$ & Sensitive \\
\hline
\end{tabular}

\section{CONCLUSION}

Exposures to environmental $\mathrm{Cr}$ have led to the development of Cr-resistant bacteria. Here, we have reported the existence of Cr-resistant bacteria in the wastes from the drains carrying tannery effluents of Bangladesh. These bacteria also showed resistance to beta-lactam group of antibiotics indicating dual existence of $\mathrm{Cr}$ tolerance and antibiotic resistance. ${ }^{21}$ These results argued that environmental exposure of heavy metals is creating antibiotic resistant microorganisms even at the absence of antibiotics by some unknown mechanism. Such event could be a potential risk for public health. Further studies will be needed to elucidate the mechanism as well as the risk factor for such incidence.

\section{ACKNOWLEDGEMENT}

We acknowledge Biotechnology Research Centre, University of Dhaka, Bangladesh for funding this research.

\section{REFERENCES}

1. Sas-Nowosielska, H. and Pawlas, N. 2015. Heavy metals in the cell nucleus - role in pathogenesis. Acta Biochim. Polonica 62, 7-13.

2. Ianeva, O.D. 2009. Mechanisms of bacteria resistance to heavy metals. Mikrobiol. Zhurnal. 71, 54-65.

3. Jomova, K. and Valko, M. 2011. Advances in metal-induced oxidative stress and human disease. Toxicology 283, 65-87.
4. Xie, H., Huang, S., Martin, S. and Wise, J.P. 2014. Arsenic is cytotoxic and genotoxic to primary human lung cells. Mutat. Res. Gen. Toxicol. Environ. Mutagen. 760, 33-41.

5. Silver, S. and Misra, T.K. 1988. Plasmid-mediated heavy metal resistances. Annual Rev. Microbiol. 42, 717-743.

6. Sterritt, R.M. and Lester, J.N. 1980. Interactions of heavy metals with bacteria. Sci. Total Environ. 14, 5-17.

7. Ahsan, N., Faruque, K., Shamma, F., Islam, M.N. and Akhand, M.A.A. 2011. Bacterial extracellular polymeric substances play role in arsenic adsorption. Bang. $J$. Microbiol. 28, 80-83.

8. Xu, C., Zhou, T., Kuroda, M. and Rosen, B.P. 1998. Metalloid resistance mechanisms in prokaryotes. J. Biochem. 123, 16-23.

9. Silveira, E., Freitas, A.R., Antunes, P., Barros, M., Campos, J., Coque, T.M., Peixe, L. and Novais, C. 2014. Co-transfer of resistance to high concentrations of copper and first-line antibiotics among Enterococcus from different origins (humans, animals, the environment and foods) and clonal lineages. J. Antimicrob. Chemotherapy 69, 899-906.

10. Bednorz, C., Oelgeschläger, K., Kinnemann, B., Hartmann, S., Neumann, K., Pieper, R., Bethe, A., Semmler, T., Tedin, K., Schierack, P., Wieler, L.H. and Guenther, S. 2013. The broader context of antibiotic resistance: zinc feed supplementation of piglets increases the proportion of multiresistant Escherichia coli in vivo. Int. J. Med. Microbiol. 303, 396-403.

11. Baker-Austin, C., Wright, M.S., Stepanauskas, R. and McArthur, J.V. 2006. Co-selection of antibiotic and metal resistance. Trends Microbiol. 14, 176-182.

12. Icgen, B. and Yilmaz, F. 2014. Co-occurrence of antibiotic and heavy metal resistance in Kizilirmak River isolates. Bull. Environ. Contamim. Toxicol. 93, 735-743. 
13. Seiler, C. and Berendonk, T.U. 2012. Heavy metal driven coselection of antibiotic resistance in soil and water bodies impacted by agriculture and aquaculture. Frontiers in Microbiol. 3, 399.

14. Akinbowale, O.L., Peng, H., Grant, P. and Barton, M.D. 2007. Antibiotic and heavy metal resistance in motile aeromonads and pseudomonads from rainbow trout (Oncorhynchus mykiss) farms in Australia. Int. J. Antimicorb. Agents 30, 177-182.

15. Papp, J.F. 1985. Chromium. In: Mineral Facts and Problems, Bulletin 675 (Knoerr, A.W., Eds.), U.S. Bureau of Mines, Washington DC, pp. 139-156.

16. Nikaido, H. 2009. Multidrug resistance in bacteria. Ann. Rev. Biochem. 78, 119-146.

17. Yamanaka, K. 2002. The Gram stain. J. Assoc. Rapid Meth. Autom. Microbiol. 12, 81-90.

18. Biemer, J.J. 1973. Antimicrobial susceptibility testing by the Kirby-Bauer disc diffusion method. Annal. Clini. Lab. Sci. 3, 135-140.
19. Dudley, M.N., Ambrose, P.G., Bhavnani, S.M., Craig, W.A., Ferraro, M.J. and Jones, R.N. 2013. Background and rationale for revised clinical and laboratory standards institute interpretive criteria (Breakpoints) for Enterobacteriaceae and Pseudomonas aeruginosa: I. Cephalosporins and Aztreonam. Clin. Infect. Dis. 56, 13011309.

20. Panda, J. and Sarkar, P. 2012. Isolation and identification of chromium-resistant bacteria: Test application for prevention of chromium toxicity in plant. J. Environ. Sci. Health 47, 237-244.

21. Resende, J.A., Silva, V.L., Fontes, C.O., Souza-Filho, J.A., Rocha de Oliveira, T.L., Coelho, C.M., César, D.E. and Diniz, C.G. 2012. Multidrug-resistance and toxic metal tolerance of medically important bacteria isolated from an aquaculture system. Microbes Environ. 27, 449-455. 